\title{
Victorian Ethics in Pre-Raphaelite Art: Depiction of the Fatale Fall of Femme
}

\author{
Azmi Azam \\ Anglia Ruskin University, Cambridge, England.
}

\begin{abstract}
Pre-Raphaelite paintings and literature depict the fallen women image in various ways. Rossetti, Hunt, Morris, Redgrave, Egg, Brown, Tennyson and so on contributed to illustrate the theme of ragged and fallen women in work of art. These works are highly inspired by medievalideas of virginity and Victorian ethics of morality. This article aims to explore the ideas of womanhood betrayed by love and condemned by male chauvinism. Various examples are given and are described to illustrate the views of fatale fall of women seeking love from men and their sexual frustration that results as a punishment for their immoral and illicit love.
\end{abstract}

Keywords: Love, betrayed, morality, passion, punishment, frustration, society, weakness, struggle, survival.

In 1848, as revolutions swept continental Europe and an uprising for social reform, known as Chartism, unsettled Britain, seven rebellious young artists in London formed a secret society with the aim of creating a new British art. They called themselves the Pre-Raphaelite Brotherhood, and the name, whose precise origin is contested, nevertheless indicates the chief source of their inspiration. Although the Brotherhood's active life lasted not quite five years, its influence on painting in Britain, and ultimately on the decorative arts and interior design, was profound. At London's Royal Academy and Free Exhibition shows of 1849, several paintings were exhibited with the cryptic initials "P.R.B."

The subject of the woman who are getting demolished by love, deceived by one-sided love, seduced by false ideals or false lovers or victimized by tragic love dominated the practices of Pre-Raphaelite paintings and poems of the nineteenth century. Without escaping the Victorian idea of feminine weakness, the Pre-Raphaelite concept of the woman as a victim are inspired by the themes of medieval romance. However, there always remains an element of unsatisfied desire or denial of romantic love. The Pre-Raphaelites interpret this idea pointing on the sensuality and sexual frustration or punishment of the female ideas that were met with both fear and fascination by most Victorians. Their works also re-fashioned this theme to include an awareness of social injustices. Most Victorian works depicted the woman alone, left to bear the brunt of shared sexual transgressions and cast out into the uncaring world. However, many Pre-Raphaelite paintings and poems include the male's presence andindicate to his role in her destruction. The weight of blame shifts is loaded on women but not to the men who have wronged the woman.

The Pre-Raphaelites portrayed the woman destroyed by various forms of love, whether unrequited, tragic or adulterous, by highlighting not only her mental imbalances but also focusing on her sexual frustration or punishment. The Victorians considered passion to be deviant; thoughts of sexuality cause insanity and thus repression was essential. With the strong societal administration of these beliefs, many Victorians lived with great shame, guilt, and fear of damnation. Pre-Raphaelite works with themes of sexual morality often highlighted the woman's frustration orpunishment, which stemmed from her sexually deviant behavior; for it was often considered unthinkable that a woman would have sexual thoughts or desires.

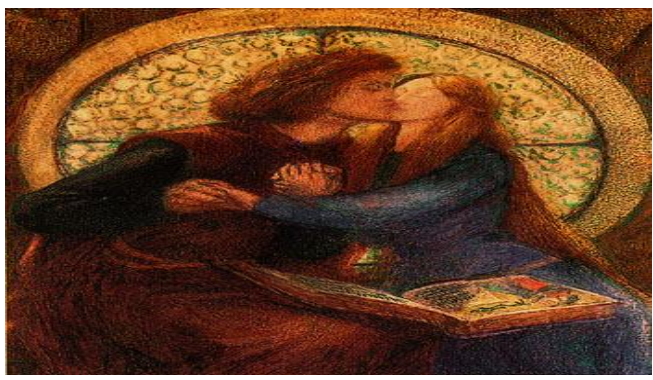

Courtesy: blocs.mesvilaweb.cat 
Dante Gabriel Rossetti's Paolo \& Francesca (1855) reflects the tragic tale of the love affair that ends in their deaths by emphasizing the lustful nature of the lovers' union. They watch the tragic lovers swept in the flaming winds of the Second Circle of Hell, in the furthest frame, as punishment for their adulterous love. Despite its forbidden nature, Francesca's love for Paolo softens her punishment and seems to survive even in Hell, further demonstrating its power. Floating, with their arms wrapped around one another in a tight embrace, their figures appear content and serene in their punishment. Unlike Augustus Egg's triptych, the artist does not use Francesca to demonstrate the immorality of adultery. Instead, Rossetti portrays the sensuality of her tragic love and seems to suggest that their love lies beyond condemnation. With his poem "The Defence of Guenevere", William Morris explains the Arthurian legend of Guenevere, which is a popular source of PreRaphaelite Brotherhood work. In a speech resembling the dramatic monologues of Robert Browning, Morris creates a realistic drama confronting the illicit romantic passion between the Queen and Sir Launcelot. Earlier in the poem, Guenevere associates herself with the innocence of springtime to elicit sympathy from her audience. However, she laterdescribes the sensual nature of their love in passionate tones.

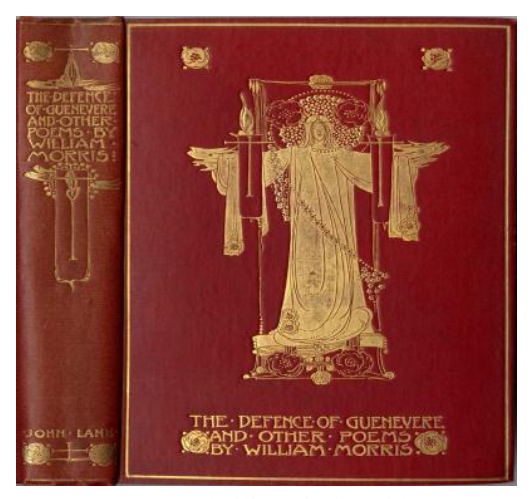

Courtesy: preraphailitepaintings.blogspot.com

Depicting as a woman guilty of any sort of sexual activity out of wedlock, the fallen woman was equated with a woman's sexual self-destruction. By stressing her passion and desire, Morris's Guenevere attempts to renounce the shame and guilt associated with adultery; however, she must still suffer for her actions. Dante Gabriel Rossetti'spoem "Jenny" (1870) features the prostitute, commonly referred to as the great societal foul in the Victorian period highlighting the sexual disproportionateness inherent to her profession.

In this poem, if one trusts the speaker with the description, Jenny is highlighted as a symbol of a ruined woman, seduced by the physical and a desiring eroticfocus in her own right. While the speaker condemns her for being impure, he wrestles with his simultaneous compassion for the prostitute and passion for the woman. Less about the fate of the young prostitute than about the inner life of the narrator, Jenny reveals the character of the prostitute who does not see the error in her ways and perhaps even enjoys her sexual freedom.

Usually portrayed as a solitary figure, the victimized woman represented by Victorian artists carry the burden of her destruction alone. Whether her undoing involved an unrequited romance or shared sexual transgressions, she often faced the uncaring world as an outcast punished as a madwoman or social rebel. Many Victorian works aimed to incite pathos and offered didactic instructions in order to avoid a similar fate. However, several Pre-Raphaelite scholars such as Richard Redgrave, tries to alter this traditional depiction and includes an awareness of social injustices that in every ruined woman's story there lay a guilty man.

A popular example, Outcast by Redgrave embodies the Victorian puritanical attitude toward sexuality. A melodramatic painting, Redgrave depicts a stern father casting out his daughter and her illegitimate baby into the literal cold, while the rest of the family weeps, pleads, or beats the wall with excessive emotion. The artist focuses on the grim fate that awaits the outcast woman in order to warn other young ladies to avoid similar temptation and ruin. On the floor lies what appears to be the incriminating letter, but her partner in crime remains absent from the scene. Augustus Egg's Past and Present series depicts a woman's infidelity to her husband and the dire consequences in three dramatic and theatrical scenes. The first, The Infidelity Discovered, shows the fallen woman's body thrown at the feet of her husband, who has just discovered her deed. Her prostrate body points to the door, indicating her outcast status and forced removal from the family. Elements of the comfortable and happy life that the woman has supposedly ruined are represented by the lavish living room and the children at play in the corner. 
The second and third paintings, The Abandoned Daughters and The Wife Abandoned By Her Lover With Her Bastard Child, continue the dark story by illustrating the consequences of her actions and their selfdestructive effects. The forlorn daughters, consoling each other by the window, and their fallen mother, huddling under a bridge, turn their respective heads to the same moon which becomes the sole connecting focal point of each piece. The only mention of the guilty man in this story remains in the first scene, as a small picture crushed under the husband's heel.

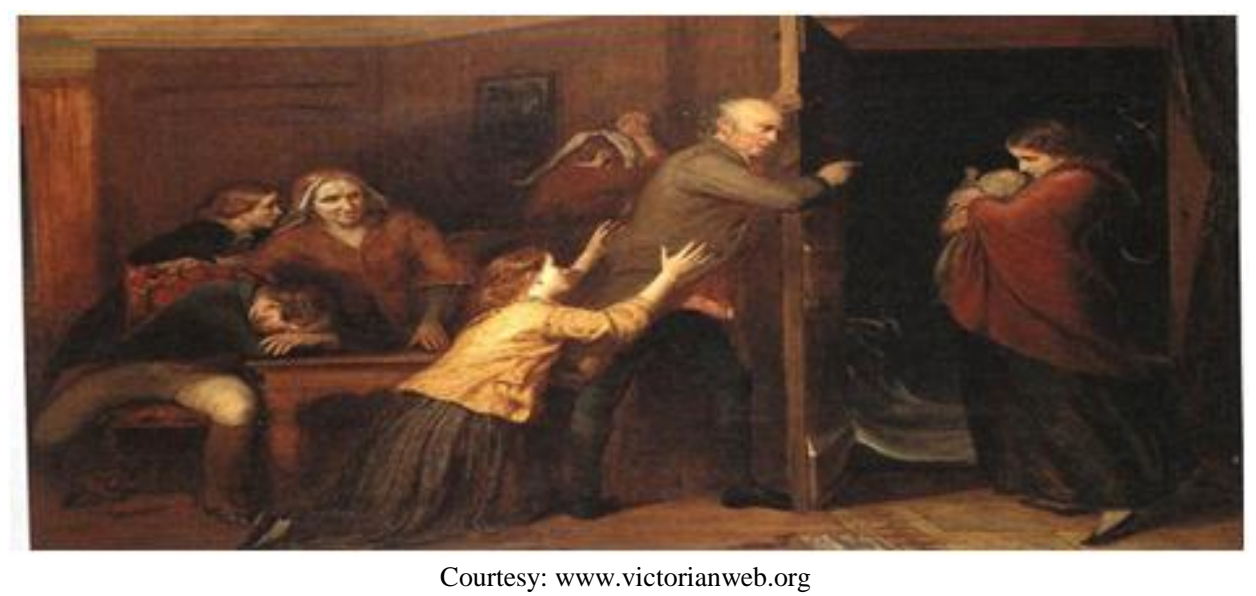

Conversely, the very presence of the male speaker in D. G. Rossetti's Jenny demonstrates the male's direct role in the fallen woman's destruction. The fact that the narrator speaks from inside the prostitute's bedroom emphasizes his personal role in perpetuating Jenny's situation, which he considers briefly in his dialogue. The reader realizes that while he sits, questioning her purity, Jenny symbolically epitomizes his own fallen nature. Holman Hunt's The Awakening Conscience also comments on this society by including the direct presence of the guilty male. Hunt's painting shows a kept mistress at the moment of her realization. She rises from her position on the man's lap and judging from his expression, he does not seem to be aware of her sudden consciousness. Captured during mid-song, his arm across her waist restricts the woman's movement and beckons her to sit back down. On the painting's frame Hunt placed a motto from Proverbs: "As he who taketh away a garment in cold weather, so is he who singeth songs unto a heavy heart". These words criticize her unfeeling seducer, who remains unaware how his words have oppressed and aided her conscience. Both works include a heightened awareness of social injustices in the adulterous affair's traditional gender roles and challenges and disperses the idea of blame.

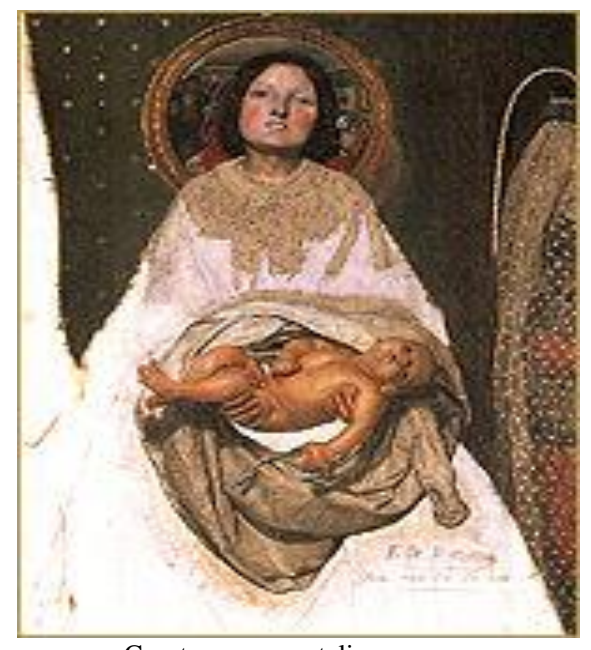

Courtesy: www.etaliapress.com

In Take Your Son Sir (1852), Ford Madox Brown confronts the theme of the fallen woman with a focus on the illegitimate child, making the shared sexual nature of the woman's transgression explicit. The idea of the illegitimate child and the fact that the adulterous woman could try to pass off this child as her husband's true offspring frightened Victorian society. In the double standard for husbands and wives, it was unthinkable that a woman would be unfaithful to her husband, but it was understood that a man might have sexual intimacies with 
more than one woman even after matrimonial allowances. As the title indicates, Brown's woman thrusts forward the offspring of an illicit union to the father's outstretched hands, reflected in the mirror. Her confrontational pose and defiant expression seems to demand shared responsibility for the child. The artist underscores the presence of the guilty man by placing the viewer of the painting in the role of the perpetrator. In a traditional scene showing the fallen woman and child, instead of displaying the typical Victorian shame and guilt, the woman seems to shows pride and challenges the viewer to confront the situation.

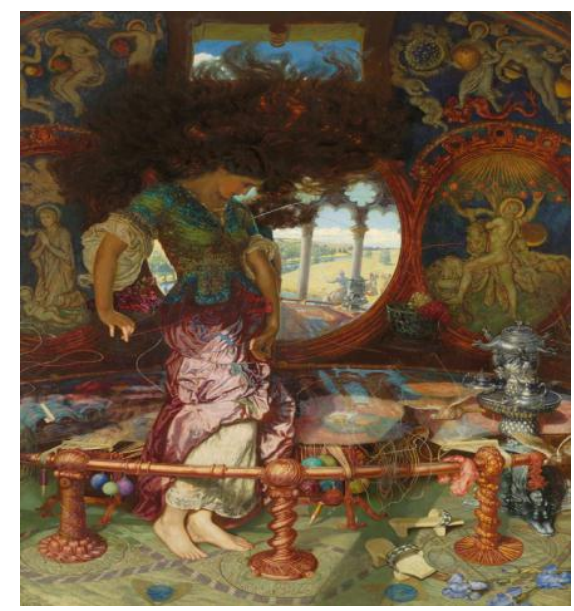

Courtesy: Islingtongovuk.j2bloggy.com

Often thought to have brought upon her own destruction; the victim of unrequited romance deserves no less support and validation for the injustice of her situation. The medieval roots of unrequited love lie in Tennyson's Lady of Shalott. As an artistic soul that longs to have a relationship with another individual, the embowered Lady lives in alone on an island, with only a mirror to see the life outside going by, she falls in love with Lancelot and pines away for him. Eventually destroyed by it, she resigns herself to death as she floats down to Camelot. The only artist to show the Lady's arrival at Camelot, D. G. Rossetti depicts Lancelot looking down at the dead Lady of Shalott in his illustration for the Moxon Tennyson. The subject of the wood engraving, the last quatrain of Tennyson's poem, emphasizes her paradoxical unraveling the Lady has given up everything, even her life, for love, and when she finally meets her love, her life is over. The chain that now ties the boat to its final moorings seems to become one with the clasps of the cloak around her neck, further sealing her fate. While it remains difficult to place blame on the unknowing Lancelot, Rossetti nevertheless alludes to his part in the Lady's death by including his presence in the design.

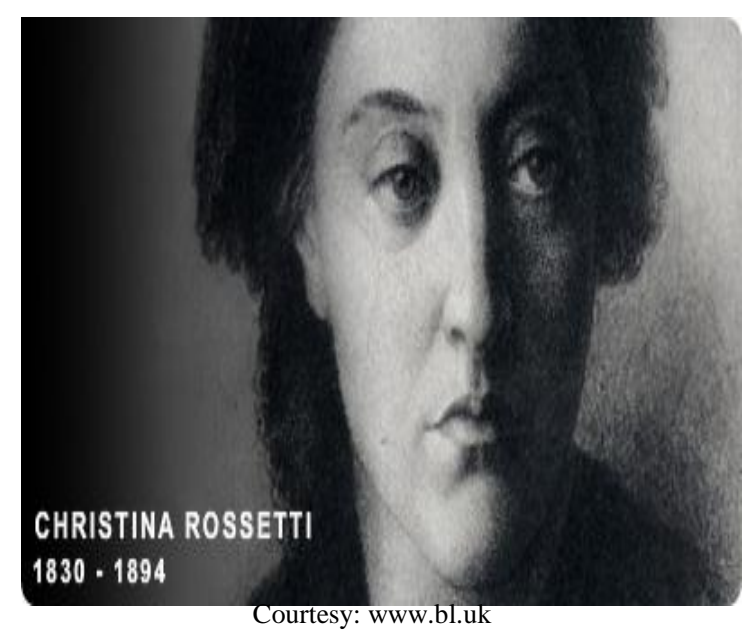

In "Light Love" (1856), fellow poet Christina Rossetti draws significant attention to the man's role in the seduction and betrayal of the female protagonist. As in many of her other poems, the woman's unhappiness is caused by the action of men who are often predatory, lazy, or lost in their own sensuality. The speaker's initial words reveal the love she still has for him, despite his betrayal. Although not a member of the Pre-Raphaelite Brotherhood, William Lindsay Windus created a painting entitled Too Late (1858) that captures another lovesick woman who literally wastes away due to her unmet desires. While the reason for her separation from 
her beloved remains ambiguous, her ruined health and broken heart are on full display for her belated lover's return. She appears sickly and frail, with sunken eyes and hollow cheeks. As a literally lovesick woman, she stands before her beloved, leaning on a crutch for support. Her haunting expression cements the pain he has caused while he turns his face away from her in agitation, pity and perhaps disgrace. Although heavily criticized by Ruskin, Windus's painting clearly illustrates the extent to which the man can affect the telling of unrequited love.

The various depictions of the woman destroyed by love, in all its forms, often conclude with her final fate which is tragic and pitiful death. Many Victorians felt that death represented an inevitable and welcome release for the lovesick or fallen woman; particularly in the case of the adulteress and prostitute. Having suffered from unrequited love, women such as Tennyson's wistful Lady of Shalott and frustrated Mariana and Windus's sickly invalid succumb to death by physical deterioration, as a manifestation of their mental state. No longer able to endure their desire for emotional and physical fulfillment, these women meet death as weakened shells of their former selves. As an extension of this mode of destruction, suicide was viewed as the inevitable course of action for the adulteress and prostitute. Already outcast from Victorian society, these women supports the common view that once a woman or girl had fallen, she was essentially unsalvageable. "The Bridge of Sighs" by Thomas Hood, describes the circumstances of the stereotypical solitary harlot and her brutalized existence from betrayed love.

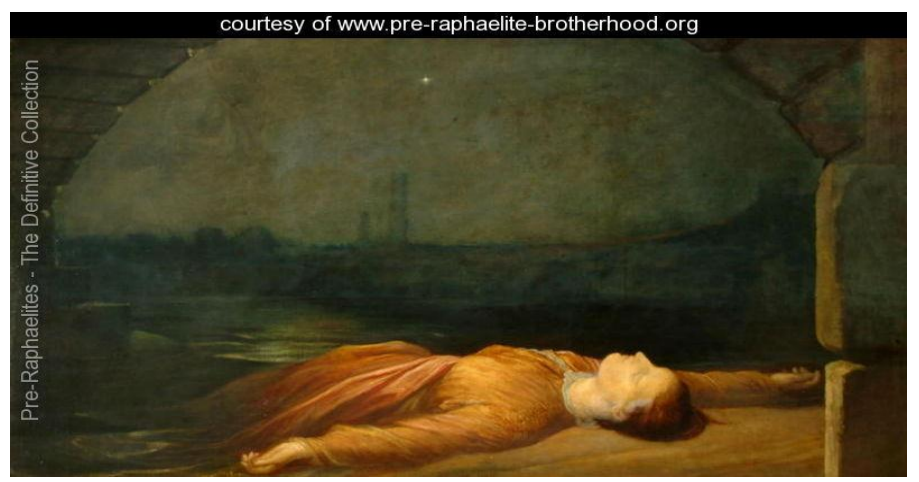

Similarly, George Frederic Watts's Found Drowned, painted in 1848, depicts a suicide washed up under the arch of Waterloo Bridge. Both works assume we understand that the woman's fate before was worse than death, and therefore death would provide a welcome respite. Hood and Watts, demonstrate the lack of sympathy for the woman who destroys her own family and happiness; and to many Victorian audiences her death sentence seemed a fitting and gracious escape.In contrast, the issue of how the fallen woman could be rescued or raised up again emerges in several Pre-Raphaelite works that present the possibility of spiritual redemption. In Morris's poem "King Arthur's Tomb”, Guenevere finally chooses a life devoted to Christ instead of returning to Lancelot. Although, she struggles endlessly with her decision. Some of the features, which are highly celebrated in this genre are:

(1) Pre-Raphaelite poetry broke with the set tradition of poets like Tennyson and revolted against the overconcern of poets like Tennyson with contemporary socio-political problems. Consequently, none of the Pre-Raphaelites concerns himself with sordid realism and the mundane issues of his day, but escapes to a self-innovative and self-centered but somehow destructive dream world.

(2) This dream world is often offered by the Middle Ages which exercises a strong hold on the minds of some Romantics like Coleridge, Keats, and Scott. Medieval Italy, being the land of artists before Raphael, held for them a very special attraction. The medievalism of the Pre-Raphaelites has a subtleness, which differentiates it from that of the Romantics before them. Some Pre-Raphaelites, such as Hunt and Millais the painter, were somewhat skeptical of medievalism but Rossetti and Morris, in particular, felt a compulsive fascination for the romance, chivalry, gorgeousness, mystery and supematuralism of the Middle Ages. Many of Rossetti's poems like The Blessed Damozel and Sister Helen are evocative of the spirit of the Middle Ages. However, it was Rossetti alone who, among the members of the original Brotherhood, exalted medievalism to a cult. Later, Morris also came under the medieval spell. Morris was particularly interested in Chaucer, the fourteenth-century English poet.

(3) The Pre-Raphaelites, as a rule, bothered more about the particular than about the general. Both in their 
paintings and their poetry we come across a persistent tendency to dwell on particular minor and major details. They do not wield a broad and hurried brush, but love to linger on details for their own sake. They tried to paint the thing itself-not a traditional copy of it. For a perfect faithfulness of description the fidelity to details was, therefore, necessary. Sometimes this concern for details degenerates into a mannered trick, but very often it strikes the reader with a forceful, concrete effect, making for freshness of perception and this tendency to linger on simple details is discernible.

(4) Like Rossetti most Pre-Raphaelites were painters as well as poets. That explains much of the sensuousness of their poetry as well as their loving concern for details. Much of their poetry is as concrete as painting and as romantic as fantasy. This mixture sometimes leads the Pre- Raphaelites to excess, giving rise to two defects: a) Too much concern for detail without thematic relevance or any other functional significance, and b) excessive recourse to luminous decorations which within limits is pleasing enough, but becomes a cloying confection for excessiveness.

(5) The sensuousness of the Pre-Raphaelites was considered blameworthy by the prudish Victorians when it came to the beauties of the human body. The Pre-Raphaelites made no bones about the exhibition of their tendencies. But it is difficult to charge them with immorality. Swinburne and others strongly reacted to the charge of Buchanan that the poetry of their school was "fleshly". Swinburne, however, was much too daring as he strucks the readers with an intensity of the feeling of shock mixed with amazement as Byron had done before him. Indeed, it is to be admitted that the Pre-Raphaelites had an emotional exaggeration, which led them to excessive sensuousness not entirely free from the immoral taint.

(6) Pre-Raphaelite poetry is rich not only in pictorial quality but also in music. The trouble is that the PreRaphaelites go to excess in both. The excessive use of alliteration and onomatopoeic effects makes often for a cloying sweetness.

Moreover, the Pre-Raphaelites focused their paintings as well as their poetry on four major subjects: Shakespeare, Dante, Arthurian legend and the Bible. As mentioned, they structured their movement on the Middle Ages, which was a time of great religious zeal in Europe, so Biblical scenes were very common. PreRaphaelite painters shared these four large themes with the literary figures of the movement, producing a body of poetic works relatable in style to that of the Romantic period (1800-1850).

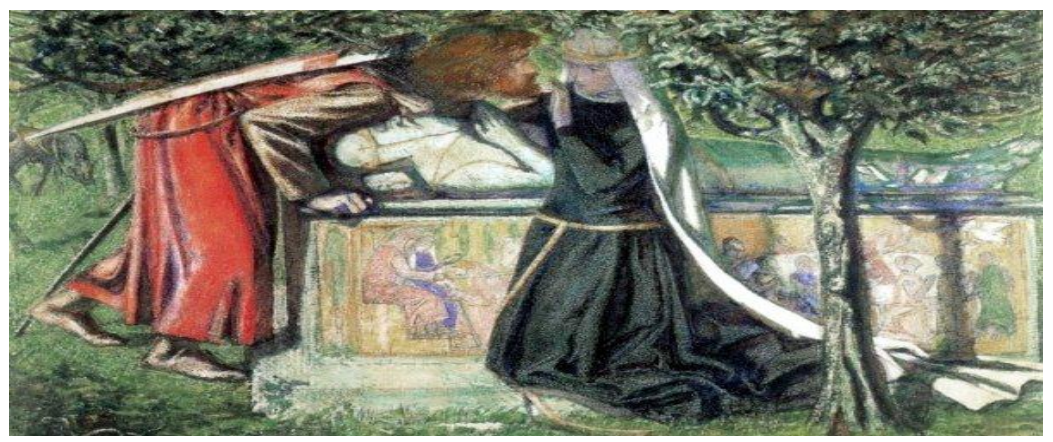

Courtesy: www.penwith.co.uk

Such depictions of the fallen woman construct her as a remorseful victim and an object of sympathy rather than condemnation, allowing for the possibility of religious salvation. Most prominently featured in Hunt's The Awakening Conscience. The artist captures his subject at the sudden moment when she realizes the reprehensibility of her actions and recognizes her powerful desire to end them. Hunt alludes to this desire with his use of symbolism, most evident in the objects included in the gaudy domestic space. Hunt chooses to focus on the hope for redemption and positions religion as the woman's savior from her sinful life. Christina Rossetti's fallen women poems, including "Light Love", often present religious redemption as the key to the woman's release. In "Light Love" the woman's lover abandons her, oblivious to her pleas, and in the end: "She raised her eyes, not wet / But hard, to Heaven / And asked / 'Does God forget?" (Poems 1:138). This stanza reassures us that while the guilty man may go unpunished on earth, he will eventually be judged in Heaven. Both Hunt and Rossetti draw upon the Christian concept of a merciful and compassionate Christ, stemming from his acceptance of Mary Magdalene, who forgives all and warns none of us to cast the first stone. By allowing for the fallen woman to be raised up again, they appeal for the audience's sympathy over condemnation and encourage us to look upon those whom we might encounter in real life with the same compassion. 
Apart from the male painters and poets, Elizabeth Siddal was one of several model-turned-artists of the Pre-Raphaelite movement. She was a model for almost all of the members of the Brotherhood, and was the primary subject of Rossetti (who was said to have painted Siddal thousands of times). It's no surprise that Rossetti and Siddal became lovers and eventually married. Rossetti taught Siddal to paint; she caught on quickly and developed her own unique style. Her self-portraits (see below) are interesting because one can compare how she perceived herself as opposed to how she was perceived by the artists she modeled for. Her other paintings (such as The Ladies' Lament, below) are characteristic of the Pre-Raphaelite movement, with their focus on nature, vivid colors, and realistic subjects. Siddal was not the only female Pre-Raphaelite artist. Another notable woman from the movement was Rosa Brett, who was taught to paint by her brother, John Brett, and focused on painting landscapes. In fact, there are at least twenty others.

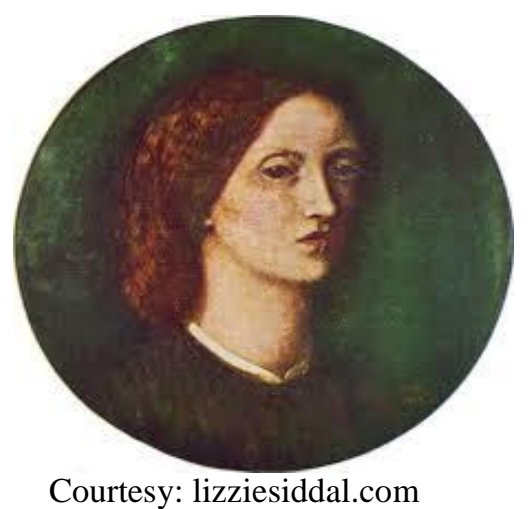

In their depictions of the destructive nature of love, whether unrequited, tragic, illicit or forbidden, the Pre-Raphaelites often aimed for a degree of realism. However, they ultimately reinterpreted the actions and sensations of the real world and merged them with their own sympathetic ideals. Following Pre-Raphaelite tradition, many of the artists and writers emphasized the role of female sexuality, desire and the element of sensual passion in the woman's mental and physical destruction. Strong and healthy sex drives, once attributed to women in the Middle Ages, and became a mortal sin during the Victorian age. Constantly looking at the medieval era for inspiration, it seems appropriate that many Pre-Raphaelites sought to restore this medieval belief and make sexuality less taboo in Victorian society. The Pre-Raphaelites' attempts to blend fine art with social history which hardly met meet success but their consciousness of social imbalances allowed them to reveal and challenge various depictions of love highlighting the concept of fallen women.

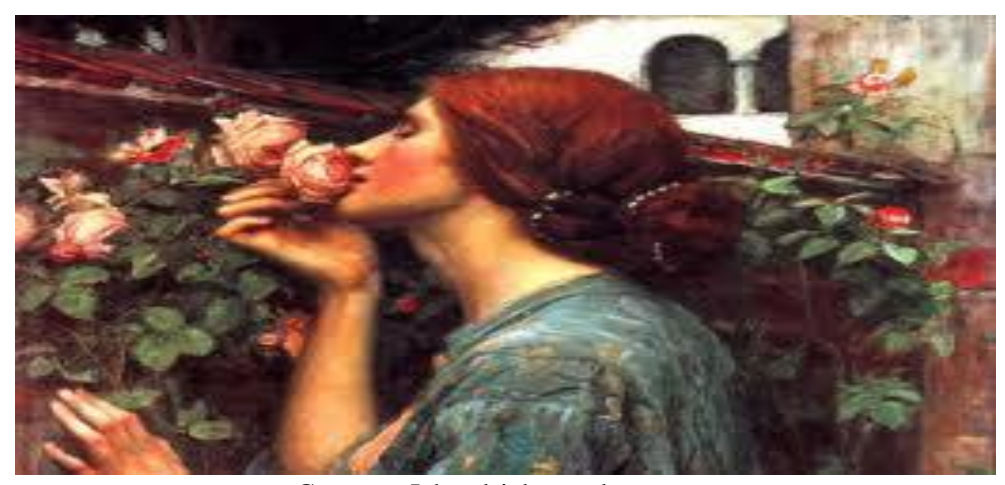

Courtesy: Inhyndsight.wordpress.com

By 1854 the members of the Pre-Raphaelite Brotherhood had gone their individual ways, but their style had a wide influence and gained many followers during the 1850s and early '60s. In the late 1850s Dante Gabriel Rossetti became associated with the younger painters like Edward Burne-Jones and William Morris and moved closer to a sensual and almost mystical romanticism. Millais, the most technically gifted painter of the group, went on to become an academic success. Hunt alone pursued the same style throughout most of his career and remained true to Pre-Raphaelite principles. Pre-Raphaelitism in its later stage is epitomized by the paintings of Burne-Jones, characterized by a jewel-toned palette, elegantly attenuated figures, and highly imaginative subjects and settings. Their concepts are now celebrated research issues and well-recognized models of art and beauty. Their works evoked new philosophies and gave new inspiration to young poets and art lovers to innovate a more dynamic and undiscovered beauty of womanhood, which is hard to justify in words or 
completely challenging to express in art. The highly imaginative world of romance which they showed in works through the depiction of critical womanhood are quintessential essences of authors' dexterity that inspires readers and fulfills the urge of pure pleasure from the faculty of intellectuality, art and romance.

\section{Bibliography}

[1]. Nochlin, L. 1978. "Lost and Found: Once More the Fallen Woman." Art Bulletin, 60.

[2]. Walkowitz, J. 1980.Prostitution and Victorian Society.Cambridge: Cambridge University Press.

[3]. Wood, Christopher. The Pre-Raphaelites. London: Seven Dials, Cassell, 1981.T

[4]. Aristotle, 1960.The Poetics: "Longliness" On the Sublime Demetrius on Style.Cambridge : William Heinemann ltd.

[5]. Cunningham, G., 1978. The New Woman and the Victorian Novel. London: Macmillan.

[6]. Crowley, D., ed., 1970. Hawthorne The Critical Heritage. London: Routledge.

[7]. Eagleton, M., ed., 1996.2 $2^{\text {nd }}$ ed., Feminist Literary Theory. Cambridge: Blackwell Publishers.

[8]. Furman, N., n. d., 'The politics of language: beyond the gender principle?'. In G. Greene and C. Kahn, eds., 1985.Making a Difference: Feminist Literary Criticism. London:Methuen.

[9]. Flint, K., 1987.The Victorian Novelist: Social Problems and Social Change.New York:Methuen.

[10]. Gerber, J.C., ed., Twentieth Century Interpretations of The Scarlet Letter New Jersey:Englewood Cliffs.

[11]. Gilmour, R., 1981. The Idea of the Gentleman in the Victorian Novel.London: George Allen \&Unwin.

[12]. Showalter, E. n. d. 'A Literature of Their Own'. In: M. Eagleton. ed. 1989.Feminist LiteraryTheory: A Reader.Oxford: Basil Blackwell.

[13]. Tompkins, J., 'Me and My Shadow'. In: L. Kauffman, ed. 1989.Gender and Theory: Dialogues on Feminist Criticism.Oxford: Basil Blackwell.

[14]. Todd, J.,1991.Feminist Literary History. Cambridge: Polity Press.

[15]. D'Amico, D. 1999. Christina Rossetti: Faith, Gender, and Time. Baton Rouge, LA: Louisiana State University Press.

[16]. Edelstein, T.J. "Augustus Egg's Triptych: A Narrative of Victorian Adultery." 125 (April 1983) Burlington Magazine.

[17]. Harrison, Anthony H. "Love and Betrayal," Christina Rossetti in Context.Victorian Web. Ed. George Landow. 1993. May 2014.Hilton, T., 1970.The Pre-Raphaelites. New York: Thames and Hudson.

[18]. Landow, George. Replete with Meaning: William Holman Hunt and Typological Symbolism. Victorian Web. 8 May 2014

[19]. Nelson, Elizabeth. "Pictorial Interpretations of 'The Lady of Shalott': The Lady in her Boat." Victorian Web. 8 May 2014.

[20]. Nelson, Elizabeth. "The Embowered Woman: Pictorial Interpretations of 'The Lady of Shalott."' Victorian Web. 8 May 2014.

[21]. Eagleton, M.,ed., 1996.2 $2^{\text {nd }}$, ed., Feminist Literary Theory. Cambridge: Blackwell Publishers.

[22]. Furman, N., n. d., The politics of language: beyond the gender principle?.In G. Greene and C. Kahn, eds., 1985.Making a Difference: Feminist Literary Criticism.London:Methuen.

[23]. Flint, K., 1987.The Victorian Novelist: Social Problems and Social Change. New York: Methuen.

[24]. Gilmour, R., 1981. The Idea of the Gentleman in the Victorian Novel.London:GeorgeAllen\&Unwin.

[25]. Showalter, E. n. d., A Literature of Their Own". In: M. Eagleton. ed. 1989. Feminist Literary Theory: A Reader. Oxford: BasilBlackwell.

[26]. Chanter, T., 2006.Gender: Key Concepts in Philosophy. London: Continuum International Publishing Group.

[27]. Lenz, C.R.S; Greene, G., and Neely, C.T., eds., 1983. The Woman's Part: Feminist Criticism of Shakespeare. Chicago: Universityof Illinois

[28]. Massai.,S., ed. 2005.World-WideShakespeares: Local Appreciation in film and performance. London:Routledge.

[29]. Mitchell, J., and Oakley, A., 1994. What is Feminism?.London: Blackwell.

[30]. Summers, A., 2000.Female Lives, Moral States.London:Thresholdpress.

[31]. Perkin, J., 1993. VictorianWomen. Cambridge: Cambridge University press.

[32]. Levine, P. 1994.Victorian Feminism:1850-1900.Florida: University Press of Florida

[33]. Kelly, J., 1984.Women, History and Theory.Chikago: University Press of Chicago.Jones, V.,1991.Women in the Eighteenth Century. London: Routledge. 